\title{
ALGUNES NOTES SOBRE EL COMPORTAMENT ELECTORAL A CATALUNYA EL 15 DE JUNY DE 1977
}

\author{
Rosa Virós \\ (Universitat de Barcelona)
}

En aquest treball es comenten breument els resultats electorals a les circumscripcions catalanes a les legislatives de juny de 1977, la distribuci6 territorial del vot i la influència de l'estructura demogràfica i sòcio-econòmi. ca en el comportament electoral en base a diverses tècniques d'anàlisi multivariant - anàlisi factorial, de components principals, de regressió múltiple. S'estudia també si les diverses unitats territorials mantenen una tela. tiva coherència amb el seu comportament a les eleccions legislatives de febrer de 1936. En darrer terme, i en base a uns primers resultats provisionals, es valora la consolidació a Catalunya d'un sistema quatripartit enfront dej bipartidisme dominant a la testa de l'Estat. 


\section{Antecedents}

El govern Suárez va presentar dintre de la legalitat franquista a les velles Corts no representatives la Llei de Reforma Política, que pretenja donar un marc jurídic per liquidar, si més no formalment, l'antic règim i obrir pas a una reforma de l'aparell institucional de l'Estat.

La Llei és aprovada per les Corts i pel poble espanyol el mes de desembre de 1976 i el govern Suárez força l'oposició democtàtica a un acord sobre la normativa electoral que regularà les properes eleccions legislatives del mes de juny de 1977, primetes eleccions democtàtiques des de les de febrer de 1936, celebrades pocs mesos abans de la Guerra Civil. La normativa electoral té la intenció clara d'afavorit les forces més mo derades $i$ és fruit d'un acord entre les forces més continuistes de l'anterior règim $\mathrm{i}$ les reformistes. ${ }^{1}$

Els 350 diputats del Congrés serien elegits en districtes plurinominals que coincideixen amb les provincies. D'entrada es concedien dos escons a cada província i se n'hi afegia un per cada 144.500 habitants o fracció superior a 70.000 . Aquesta disposició perjudicava les províncies més urbanitzades $i$ beneficiava les agràries, tradicionalment més consetvadores.

A Catalunya if corresponien 47 diputats: 33 per Barcelona, 5 per Girona i Tarragona i 4 per Lleida.

En contra del sistema majoritari de la República, s'estableix per primera vegada a Espanya el sistema electoral proporcional segons la modalitat de Hondt, que acostuma en principi a afavorir les formacions polítiques més importants $i$ que en les circumscripcions electorals amb pocs escons a repartir funciona en la pràctica gairebé com un sistema majoritari. S'establia també que tots els partits o coalicions que no superessin

1. Llei de Reforma Política de 18 de novembre de 1976; Reial Decret-Llei de 18 de març de 1977 sobre Normes Electorals; Llei de 17 de juliol de 1978 sobre Eleccions Locals. 
el 3 per cent de vots vàlids emesos en cada circumscripció electoral no podien participar en la distribució d'escons.

Quant al Senat o segona Cambra establerta per la Llei de Reforma Política -207 senadors electius més els de lliure designació del Rei--, cada província havia d'elegir 4 senadors segons el sistema majoritari, la qual cosa agreujava la subrepresentació de les zones més industrialitzades i progressives.

Les eleccions així plantejades, en base a una legislació no pactada lliurement sinó «atorgada» des del poder, havien de complir, malgrat tot, la funció d'eleccions constituents, però se"'s va negar aquest caràcter per tal de no donar una imatge de ruptura amb el règim anterior, ruptura contrària a tota la filosofia de la Reforma Política, que solament pretenia una benedicció democràtica a la coalició de forces moderades i conservadores que, sorgides la majoria d'elles del si del franquisme, s'agrupen en una formació política llançada des del govern: la Unión de Centro Democrático.

A Catalunya el context polític pre-electoral té la seva fisonomia pròpia amb l'existència de formacions nacionalistes $\mathrm{i}$ esquerranes que assumeixen la reivindicació d'un estatut d'autonomia que faci possible un autogovern català i amb I'absència notòria de nuclis organitzats que puguin representar el paper que a la resta de l'Estat té el partit impulsat des del govern.

A les circumscripcions catalanes es presenta un ventall de formacions polítiques que van des de partits o coalicions que volen reproduir partits històrics, com la Lliga o l'ERC, fins a la coalició «Pacte Democràtic per Catalunya», que agrupava al voltant de Convergència Democràtica de Catalunya diverses forces nacionalistes, i a altres formacions d'inspiració marxista PSC-PSOE i PSUC, sense implantació històrica important a Catalunya. Els grups més continuistes s'apleguen a Alianza Popular i una sèrie de personalitats d'ideologia heterogènia Ilancen també a Catalunya una candidatura d'UCD.

\section{Els resultats de les eleccions}

Només set candidatures es presentaven a totes quatre circumscripcions catalanes - Alianza Popular, Unión de Centro Democrático, Unió de Centre i de la Democtàcia Cristiana de Catalunya, Pacte Democràtic per Catalunya, Esquetra de Catalunya, Socialistes de Catalunya (PSC-PSOE) i Partit Socialista Unificat de Catalunya. ${ }^{2}$ Són precisament aquestes candidatures

2. La relació de candidatures i els resultats complets obtinguts a tots els municipis de Catalunya es poden consultar a «Resultats a Catalunya de les eleccions de 
les que van assolir representació parlamentària concentrant el 93,8\% dels vots vàlids (vegeu la Taula 6). Així, doncs, la dispersió de vot va ésser mínima malgrat el gran nombre de candidatures presentades i l'efecte fraccionalitzador que s'atribueix al sistema electoral proporcional. L'abstenció va ésser d'un 20,7 - lleugerament inferior a la mitjana de l'Estat espanyol- $\mathrm{i}$ els vots blancs i nuls van representar aproximadiment un $1 \%$ dels vots emesos. En la Taula 13 podem veure l'orientació esquerrana de Catalunya, on els socialistes són votats per un $22 \%$ de l'electorat, la qual cosa representa un $28 \%$ dels vots emesos i on els comunistes obtenen un èxit incomparablement més important que el PCE a la resta de l'Estat. Les formacions majoritàries d'esquerta obtenen a Catalunya una força comparable a la que tenen a França $i$ a Itàlia, $i$ en alguns municipis importants —Sabadell, Tetrassa-- obtenen la majoria absoluta. El Pacte Democràtic per Catalunya assoleix un tercer lloc ex-equo amb UCD. No bi ha dubte que el Ilançament a datrera hora d'una candidatura del partit del govern dividia el vot conservador i moderat català, la qual cosa, però, preservà la imatge progressista del $\mathrm{PDC}$, que quedava aparentment situat en un lloc de centre real.

\section{TAULA 1}

Matriu de correlacions de les principals opcions electorals a Catalunya el 15 de juny de 1977 (analisi per comarques)

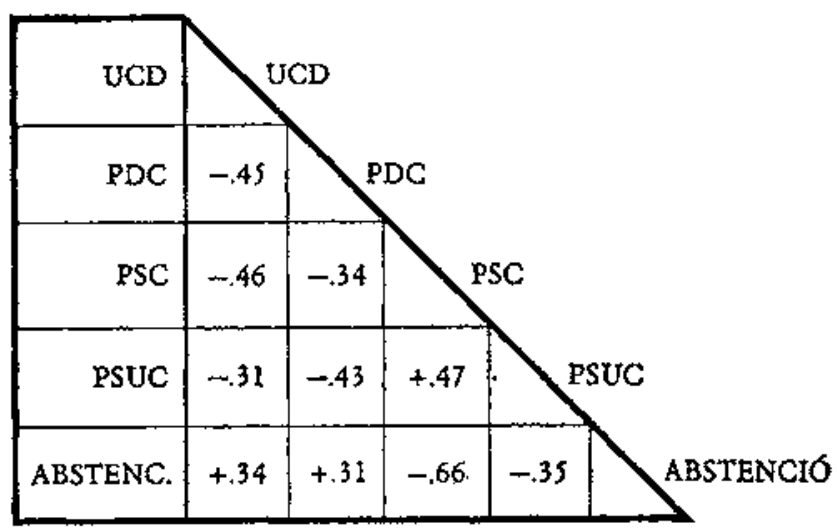

15 de juny de $1977 \gg$ - cinc volums i un resum-publicats per l'Equip de Sociologia Electoral de la Universitat Autònoma de Barcelona amb la collaboració del Consorci d'Informació i Documentacio de Catalunya, Barcelona, 1978. 
La Unión de Centro Democrático, malgrat beneficiar-se de la imatge del president Suárez i de la TV estatal, va assolir uns resultats molt més febles que a la testa de l'Estat, mentre que Alianza Popular obté amb prou feines el $3 \%$ sobre els vots vàlids - barreta mínima per assolir representació parlamentària-, la qual cosa sembla confirmar el refús de l'electorat català a les posicions més continuistes.

El repartiment d'escons materialitza els defectes de proporcionalitat del mètode de Hondt. La coalició més beneficiada va ésser el PDC $\mathrm{i}$ una de les més perjudicades Esquerra de Catalunya. ${ }^{3}$

\section{La distribució territorial del vot}

A les comarques lleidatanes es reparteixen els dos primers llocs UCD i PDC, alternativament. A la majoria de comarques tarragonines guanya la UCD, i els socialistes ocupen el segon lloc menys al Priorat i al Baix Camp, on guanyen. A la majoria de comarques gironixes guanya el PDC en lluita més o menys aferrissada amb el PSC, que assoleix el primer lloc al Baix Empordà $\mathrm{i}$ al Ripollès. A la circumscripció de Barcelona predomina gairebé arreut la candidatura «Socialistes de Catalunya» en competència amb el PDC, excepte al Barcelonès, Baix Llobregat i el Gatraf, on el segon Iloc és per al PSUC, que guanya en una comarca —Vallès Occidental.

En el Gràtic 1 -anàlisi de components principals- podem veure la situació de les comarques catalanes respecte als 4 primers partits i ens permet comprovar la relativa homogeneïtat de comportament de les comarques de cada circumscripció electoral.

Si sumem els vots del PSC, PSUC i EC per una banda i, per l'altra, els de AP, UCD i UCDCC, tindrem les zones de tendència esquertana $i$ dretana (vegeu Mapes $5 i$ 7). La primera encercla l'àrea barcelonina i s'estén cap a Girona i sobretot cap als nous pols de desenvolupament industrial de Tarragona; la segona comptèn Lleida $\mathrm{i}$ una part de Tarragona - Catalunya nova- mentre que a les comarques de Gitona hi té una bona implantació el PDC (vegeu Mapa 6). L'abstenció (vegeu Mapa 8) afecta primordialment la Catalunya interior i sobretot les comarques de l'anomenada Catalunya pobra.

3. El PSC-PSOE obté el $28,4 \%$ dels vots i el $31,9 \%$ d'escons; el PSUC el 18,2 de vots $i$ el $17 \%$ d'escons; el PDC el 16,8 \% de vots i el 23,4 $\%$ d'escons; Ia UCD el $16,8 \%$ de vots i el $19,1 \%$ d'escons; UCDCC el $5,5 \%$ de vots i el $4,2 \%$ d'escons; EC el $4,6 \%$ de vots $i$ el $2,1 \%$ d'escons, i AP el $3,5 \%$ de vots i el $2,1 \%$ d'escons. 
Mitjançant una anàlisi de correlacions " podem esbrinar el grau de compatibilitat territorial de les candidatures més importants - vegeu Taula 1. Els resultats ens confermen que a Catalunya hi ha zones on predominen AP i UCD i on l'abstenció és important, d'altres on coincideixen socialistes $i$ comunistes $i$ on la participació electoral és elevada. El PDC té les seves pròpies zones d'implantació, essent major la seva incompatibilitat territorial amb UCD i PSUC. De tota manera, cal tenir present que aquestes correlacions varien si es tealitza l'aràlisi independentment per a cada una de les quatre circumscripcions electorals i prenent com a unitat d'anàlisi el municipi i no la comarca, entre altres coses perquè l'espai po lític que ocupa cada candidatura no és forçosament el mateix a cada circumscripció. ${ }^{\mathrm{s}}$

En aquest brevíssim tesum no podem deixar de fer una allusió a l'elecció del Senat, en la qual la candidatura a què donaven suport socialistes i comunistes va obtenir 12 dels 16 escons que corresponien a $\mathrm{Ca}$ talunya $i$ els restants es van tepartit entre UCD -2-, PDC -1-i i el candidat independent Xirinacs.

És important fer notar l'extraordinària correlació entre els tesultats de les candidatures per al Senat de AP, UCD i PSC-PSUC — «Entesa»$i$ els vots que per al Congrés obtingueren els mateixos partits i coalicions. No sembla haver.hi una disciplina de vot tan gran entre els votants de UCDCC i PDC en el Congrés i la candidatura comuna per al Senat «Democràcia i Catalunya».

\section{La influència de l'estructura demogràfica i sòcio-econòmica en el comportament electoral}

En estudiar els mapes de l'esquerra, dreta i PDC i els coeficients de correlació entre candidatures, veiem com es dibuixaven unes zones o espais molt diferenciats des del punt de vista del comportament electoral. Es tracta ara de veure si aquestes zones presenten unes característiques demogràfiques $\mathrm{i}$ sòcio-econòmiques diferents.

Si examinem els Mapes 1 al 4 veurem com, a gtans trets, les grans tendències electorals es corresponen amb Ia Catalunya rutal -dreta- i amb la industrialitzada i urbanitzada -esquerra.

4. Per a 38 unitats -comarques- $x$ és signiffativament diferent de 0 a partir de 0,3202, amb un marge d'error de 0,05.

5. Vegeu Rosa Virós, Anàlisi estadística del comportament electoral a Catalunya en les eleccions legislatives del 15 de juny de 1977, Estudis Electorals núm. 2 (BarceLona: Blume, 1979). 
«Papers»: Revista de Sociologia
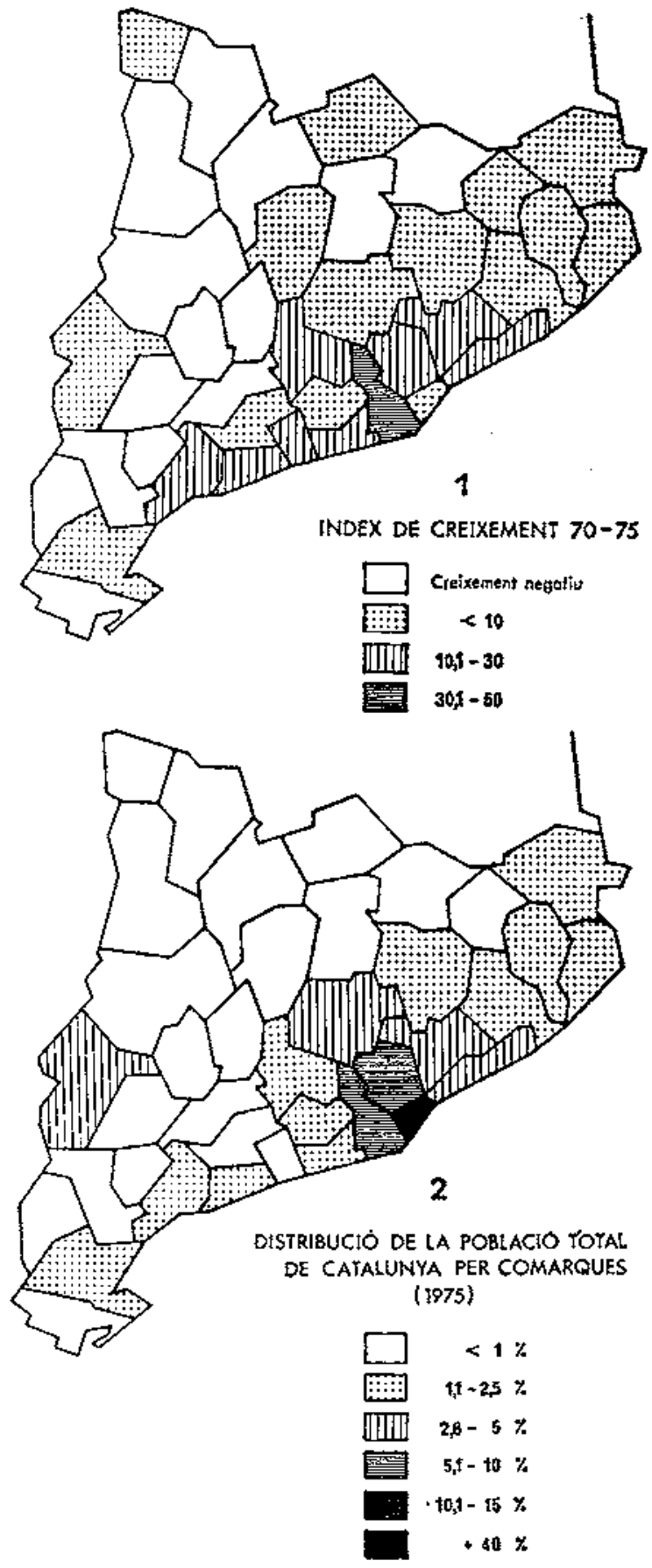
Comportament electoral a Catalunya el 15 de juny de 1977

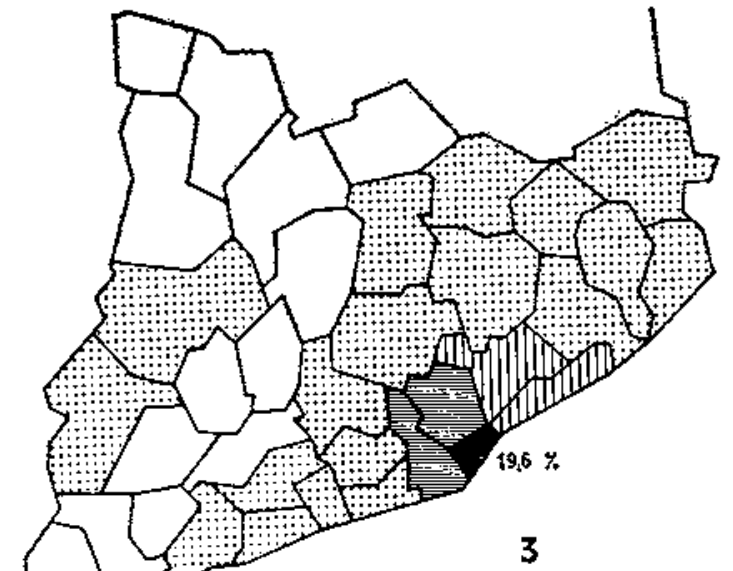

DISTRIBUCIÓ DEL TOTAL DE LA IMMIGRACIO PER COMARQUES \{CID.C. 1970\}
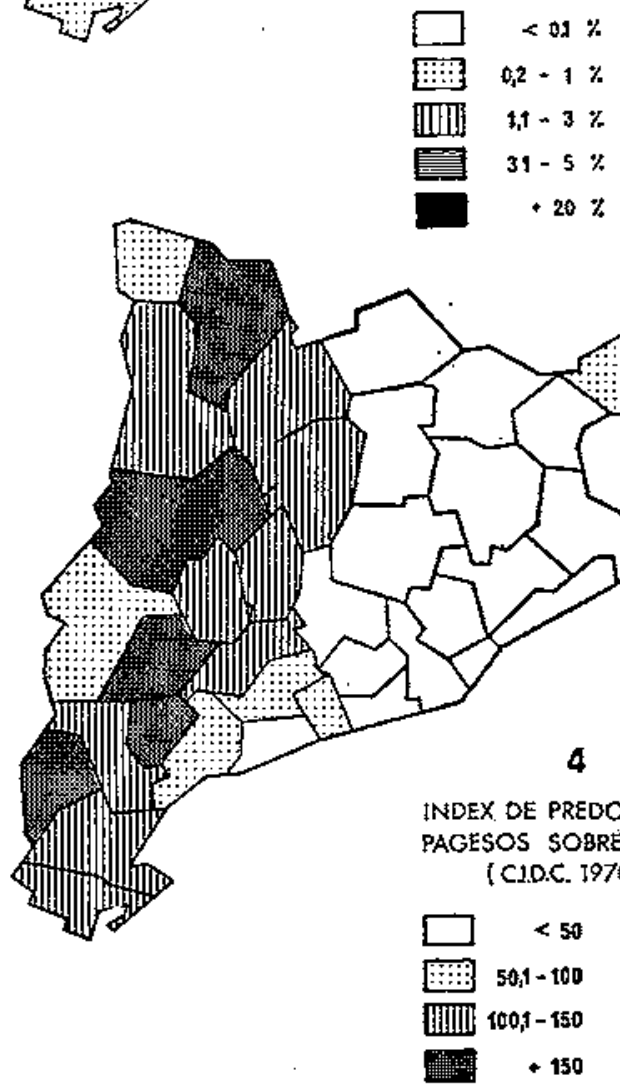
«Papers»: Revista de Sociologia
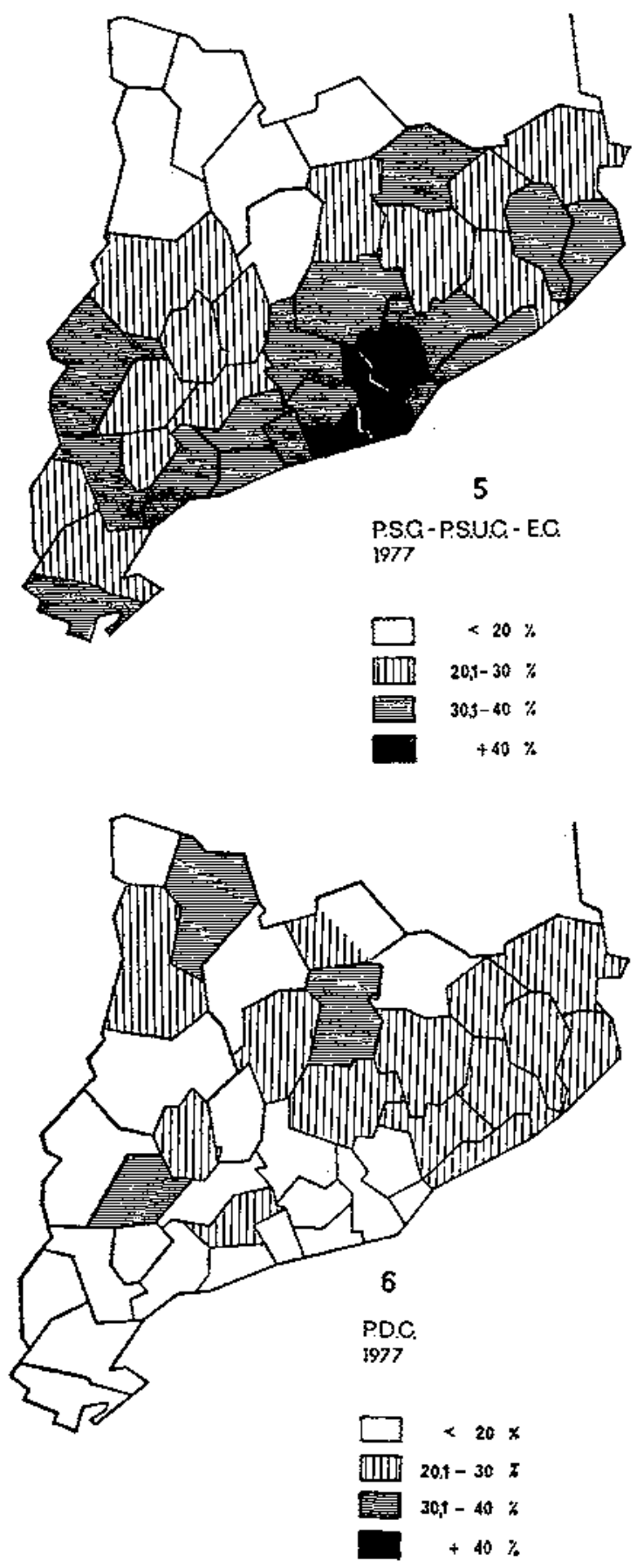
Comportament electoral a Catalunya el 15 de juny de 1977
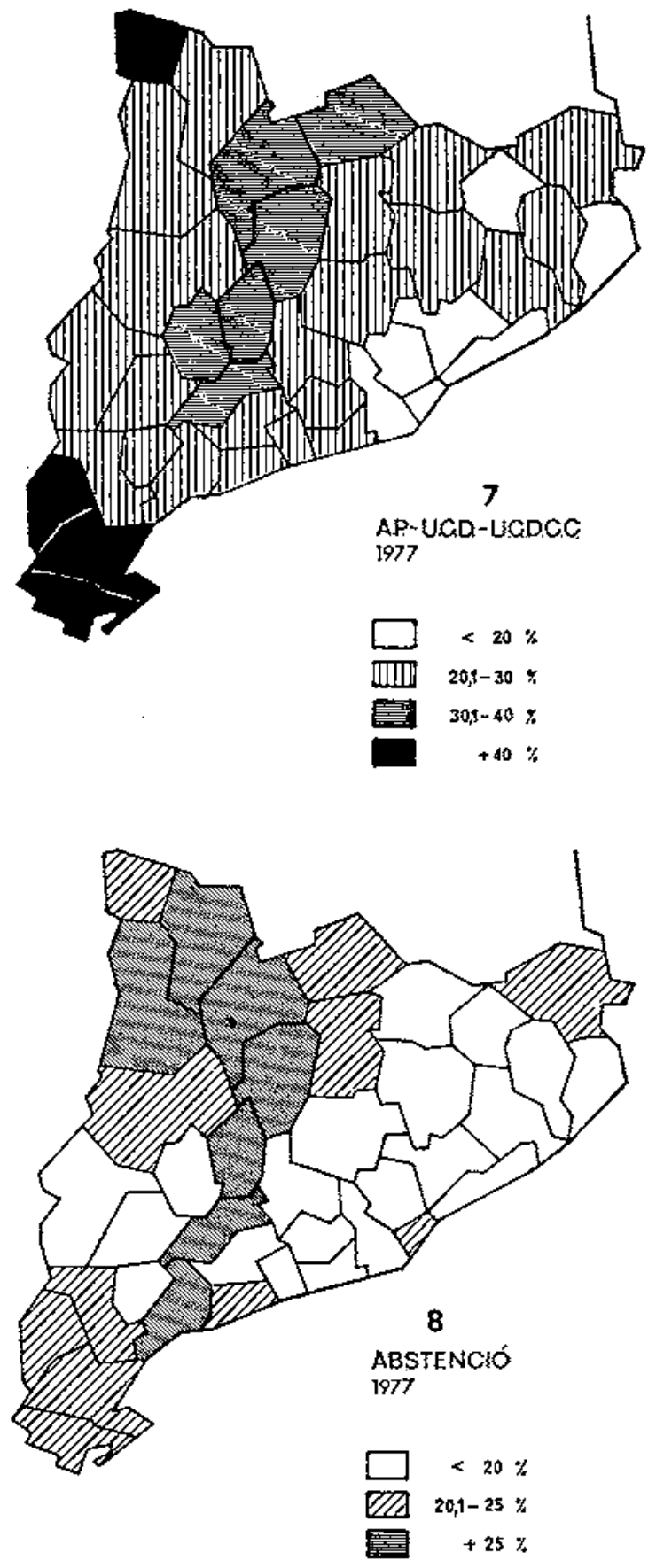
«Papers»: Revista de Sociologia

\section{TAULA 2}

Correlació d'algunes variables sòcio-econòmiques amb les principals candidatures i l'abstenció, a Catalunya (1977) (anàlisi per comarques)

\begin{tabular}{|c|c|c|c|c|c|}
\hline \multirow{2}{*}{$\begin{array}{l}\text { CANDIDATURES } \\
\text { VARIABLES } \\
\text { SOCIO. } \\
\text { ECONOMIQUES }\end{array}$} & \multicolumn{5}{|c|}{15 - JUNY - 1977} \\
\hline & UCD & PDC & PSC & PSUC & $\begin{array}{l}\text { ABS- } \\
\text { TEN } \\
\text { CIO }\end{array}$ \\
\hline $\begin{array}{l}\text { CREIXEMENT } \\
70 / 75\end{array}$ & -.32 & -34 & +.68 & +.59 & -.48 \\
\hline$\%$ AGRICULTORS & +.54 & +.04 & -.67 & -.40 & +.48 \\
\hline$\%$ ASSALARIATS & -.60 & -.00 & +.70 & +.46 & -.53 \\
\hline$\%$ IMMIGRATS & -39 & -.30 & +.64 & +.68 & -.35 \\
\hline $\begin{array}{l}\text { SNDEX PRÃCTICA } \\
\text { DOMINICAL }\end{array}$ & +.07 & +.44 & -.59 & -.67 & 4.50 \\
\hline $\begin{array}{l}\text { RENDA PER } \\
\text { CAPITA }\end{array}$ & .00 & -.23 & +.32 & +.17 & -.13 \\
\hline
\end{tabular}

El que és evident és que Catalunya pateix un fort desequilibri, motivat per la concentració de la indústria en determinades zones, la qual cosa motiva una concentració paralleia de la població que gravita sobre l'àrea barcelonina i la costa. Aquest desequilibri demogràfic ve de lluny, però es va agreujant contínuament condemnant mitja Catalunya a la deseztització. ${ }^{6}$

Si a nivell de comarques $i$ grans espais geogràfics queda ben clara la influència de l'estructura sòcio-econòmica en les grans tendències del comportament electoral, aquesta correlació no queda tan clara quan reduïm la unitat d'anàlisi als municipis i examinern també per separat les diverses candidatures.

6. L'any 1936 el cens electoral de la circumscripcí de Barcelona representava el $64,5 \%$ sobre el cens electoral de Catałunya. L'any 1977 aquesta circumscripció concentra el $77,6 \%$ del cens electoral. 
A nivell global de Catalunya - vegeu Taules 2 i 3- podem dir que el PSC-PSOE $i$ el PSUC tenen incidència en comarques amb un índex elevat de creixement, amb immigració important i amb forta concentració d'assalariats, és a dir, en contextos progressius amb una elevada renda per càpita. AP i UCD fan els seus millors resultats en comarquues amb la majotia de la població activa dedicada a l'agricultura, zones moltes d'elles en regressió demogràtica. El PDC sembla incidir en comarques mixtes, amb indústria però també amb agricultura, amb un percentatge no massa fort d'immigrants. Quant a l'abstenció, és molt més important en les zones rurals tradicionals amb un elevat índex de pràctica dominical.

$\mathrm{Si}$ realitzem l'andlisi de correlacions per a cada citcumscripció per separat $i$ utilitzem com a unitat base els municipis, no hi ha gaires indicadors sòcio-econòmics que semblin tenir una infuència en el comportament electoral. ${ }^{7}$ A les circumscripcions de Barcelona i Lleida, que són els dos extrems en l'escala d'urbanització-ruralitat i possiblement a causa de la seva major homogeneïtat, és on es donen unes correlacions més elevades entre estructura sòcio-econòmica i comportament electoral, sobretot respecte a les forces d'esquerra, que acostumen a tenir ia seva implantació concentrada en espais molt concrets. El PDC és el que presenta correlacions més baixes, essent només significativa i de caràcter negatiu Ia que té amb la inmigració. Realitzada una analisi factorial per tal d'esbrinar quins són els factors o eixos que expliquen més bé la diferenciació sòcio-econòmica dels municipis catalans, es configura com el més important el d'urbanització-ruralitat $\mathrm{i}$ en segon lioc el d'industrialització, que oposa indústria petita a la intermèdia $i$ gran $i$, en altres indrets, la industrialització recent a la més antiga.

Tambe hi ha altres factors especifics per a cada circumscripció, com per exemple un factor tercerització-turisme per a Girona i un factor de regressió demogràfica per a Lleida.

Quant als factors electorals, els més importants són:

1. Un factor d'esquerra-dreta, que a Catalunya és en realitat un factor d'esquerra-centre, que delimita zones, amb un fort predomini dels partits i coalicions d'esquerra enfront d'altres més conservadores, en les quals es disputen l'hegemonia el centre nacionalista -PDC - i el centre progovernamental - UCD.

2. Un factor centre, que separa zones favorables a UCD d'altres comarques on predomina el catalanisme històric del PDC.

7. Sobte la influència dels indicadors sòcio-econòmics en el comportament electoral del 1977, vegeu M. Terradas, Les eleccions del 15 de juny a les comarques giro. nines (Girona: Collegi Universitari de Girona, 1978); Rosa Virós, op. cit. 
«Papers»: Revista de Sociologia

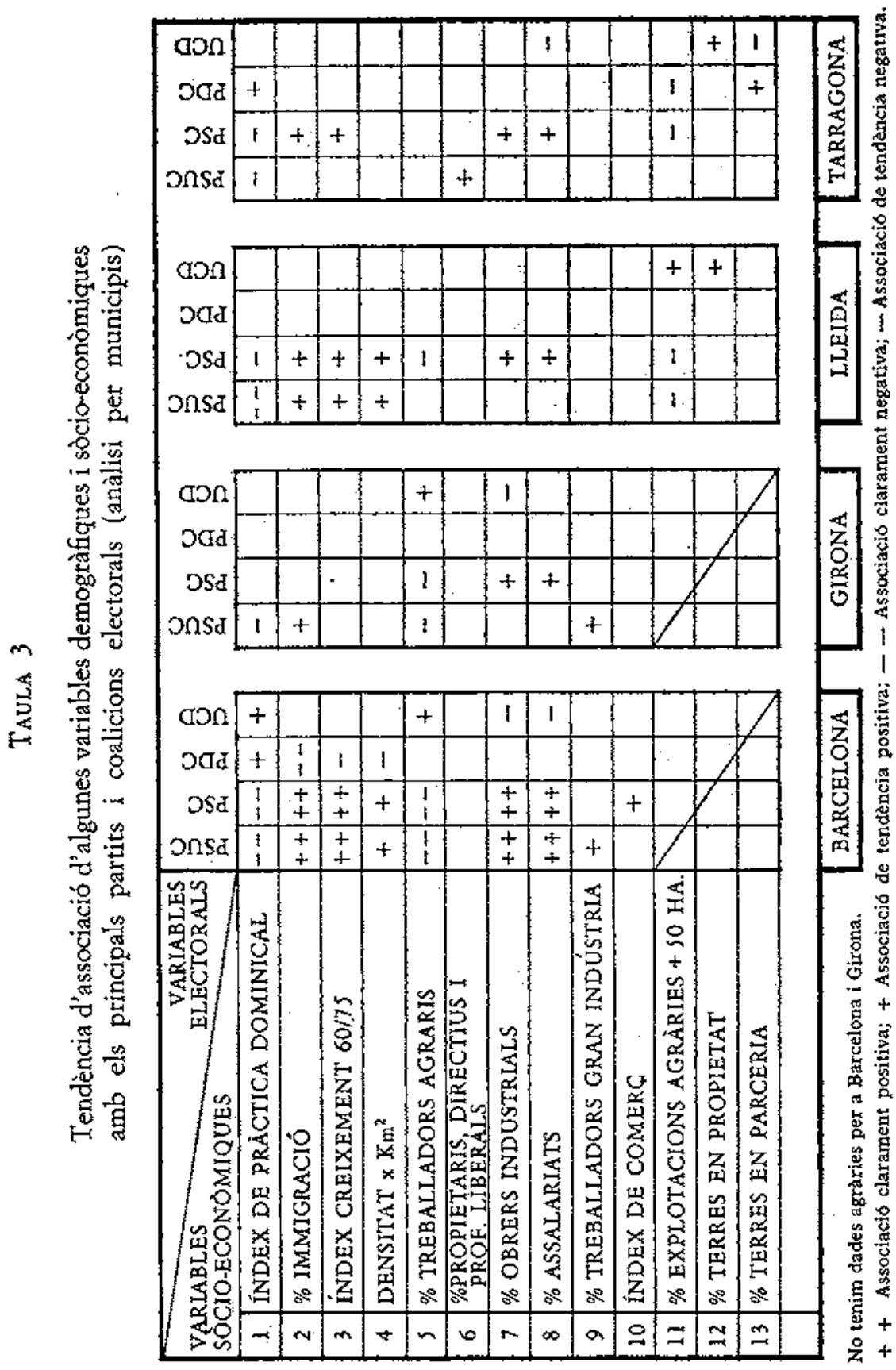


3. Un factor dreta continusista -AP-, que té una certa incidència a Tarragona.

4. Un factor abstenció, important sobretot a les comarques de Lleida.

Realitzada la correlació entre factors sòcio-econòmics i electorals, ob. servem que els únics que tenen una associació important són el factor urbanització-ruralitat amb el factor esquerra-dreta, dibuixant-se com a primordialment ideològic el que oposa centre nacionalista a centre pro-governamental, que no té associació significativa amb els factors demogràfics $i$ sòcio econònics (vegeu Gràtic 1).

Més enllà del grau d'associació entre les variables —coeficients de correlació- podem emprar les variables sòcio-econòmiques per determinar el vot obtingut per les diferents coalicions electorals mitjançant una anàlisi de regressió múltiple. És a dir, a partir d'una combinació de variables intentern determinar el vot obtingut per les diferents coalicions electorals minimitzant la desviació mitjana dels residus o difetències entre els vots «esperats» $\mathrm{i}$ els obtinguts. Teòricament, com més s'ajusti la combinació d'indicadors sòcio-econòmics als resultats més fàcil serà en futures eleccions predir a partir d'aquests les votacions dels diferents partits. L'anàlisi de regressió múltiple tealitzada per a les 4 circumscrip. cions catalanes ens confitma el que apuntàvem abans: que solament els resultats del PSUC i del PSC poden ésser explicats o determinats en una bona part a partir de l'estructura material.

Els indicadors més explicatius són a Barcelona la Immigració per al PSUC (+), PSC (+) i PDC (-) i el \% de propietaris, directius $i$ professions liberals pex a UCD $(+)$. A Girona la Immigració per al PSUC $(+)$, i el \% d'assalariats per al PSC (+). A Lleida l'index de pràctica dominical per al PSUC (-) i el PSC (-) i el \% d'obrers i empleats per a UCD (-). A Tarragona l'index de pràctica dominical per al PSUC (-), PSC $(-)$ i $\operatorname{PDC}(+)$.

Com a conclusió sobre tot el que hem dit sobre la influència de l'estructura material en el comportament electoral i tenint present que el grau de predictibilitat del vot correspon al seu grau de determinació i que 'associació amb els indicadors sòcioeconòmics ens indica un cert index de necessarietat enfront de l'aleatorietat del comportament electoral, podem concloure que el nacionalisme centrista apareix amb arrels estructurals difícilment detectables, la qual cosa sembla confirmar el caràcter suprastructural $\mathrm{i}$ ideològic del vot rebut, d'acord amb les propostes de la seva campanya electoral i la imatge de les seves candidatures simplement catalanes. EI vot comunista es troba en l'altre extrem de màxima determi* nació. El vot del PSUC correspon a unes estructures sòcio-econòmiques 
«Papers»: Revista de Sociologia

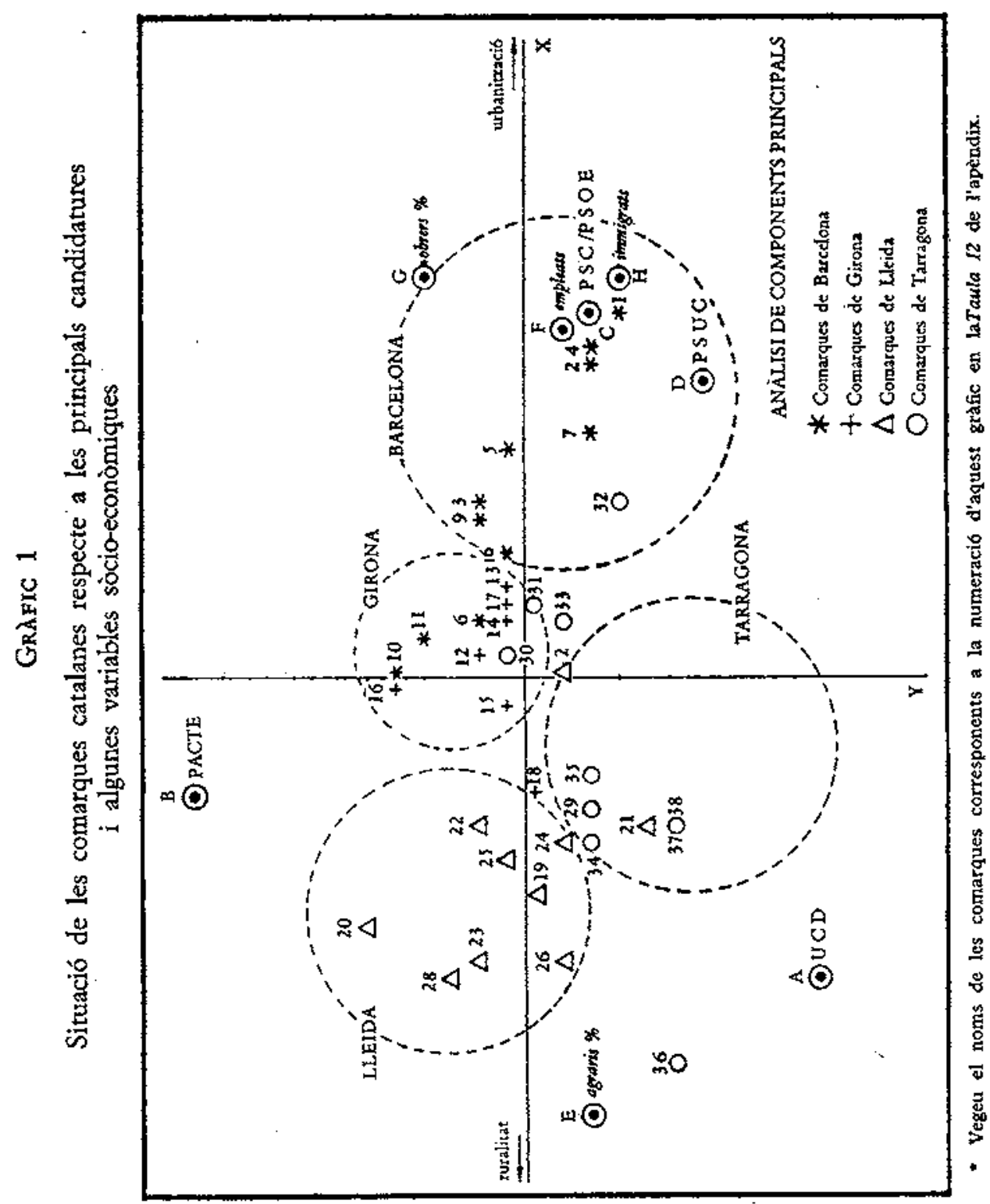


concretes, la qual cosa sembla apuntar a una gran estabilitat de la seva força en el futur sempre que es mantingui estable el context sòcio-econòmic.

El vot dels socialistes sembla més interclassista - -segons el concepte tradicional de classe-, més d'una nova classe assalariada dels treballadors en general i no solament dels obrers industrials.

El vot favorable al partit del govern - UCD - és sens dubte el més polític, ja que, malgrat estar relativament condicionat per l'estructura sòcio-econòmica, és altament aleatori i pot ésser més sensible a la conjun. tura i a la gestió governamental i fins $\mathrm{i}$ tot a la permanència d'UCD en el govern.

¿Hi ha relació entre el comportament electoral de juny de 1977 $i$ el de febrer de 1936 ?

Després de quaranta anys d'absència d'eleccions democràtiques resulta interessant veure si es mantenen unes línies profundes de tradició de vot en les comarques de Catalunya."

$\mathrm{Si}$ agrupem les forces d'esquerra -PSC-PSUC i EC- i les comparem amb el Front d'Esquerres de 1936 (vegeu Taules 12 i 14) trobarem que, en general, les comarques gironines $i$ tarragonines tendeixen a comportar-se d'una manera semblant mentre que s'incrementa l'esquerra en les comarques de Barcelona, sobretot en aquelles que han sofert un procés d'industrialització posterior, com el Valiès Oriental i el Baix Llobregat. La Cerdanya i la Vall d'Aran són potser les comarques en què l'esquerra ha perdut més posicions. Si esguardem els coeficients de correlació veurem que no hi ha, a nivell territorial, massa relació entre el Front d'Ordre de 1936 i els partits i coalicions de centre i dreta de 1977. La correlació es dóna certament si sumem aquests, però, ¿què cal fer amb PDC, que tenia uns plantejaments de populisme nacionalista però que de fet en alguns Hocs ocupa en l'espectre politic el lloc de formació moderada que canalitza majoritàriament part del vot conservador català que s'oposa per una banda ats partits d'esquerra i per l'altra al partit del govern -UCD?

Les correlacions del Front d'Esquerres són més significatives i ens mostren una associació negativa amb les candidatures de Dreta i Centre de 1977 i altament positiva amb les formacions esquerranes (vegeu Taula 4). Això ens confirma que es manté en profunditat la tradició de vot

8. Sobre la importància de la tradició electoral en el comportament electoral, vegeu V. Martín Moreno i A. de Miguel, Memoria bistórica e inteligencia sociológica en las elecciones españolas de 1977, Estudis Electorals núm. 1 (Barcelona: Fundació Jaume Bofill, 1978). 
«Papers»: Revista de Sociologia

dels grans espais geogràfics: Catalunya costanera, Catalunya interior i Area barcelonina.

\section{TAULA 4}

Correlació de les variables electorals de febrer de 1936 amb les de juny de 1977 (anàlisi per comarques)

\begin{tabular}{|l|c|c|c|c|c|c|}
\hline 1936 & AP & UCD & PDC & PSC & PSUC & ABST. \\
\hline $\begin{array}{l}\text { FRONT } \\
\text { D'ESQUERRES }\end{array}$ & -.46 & -.23 & -.33 & +.66 & +.56 & -.55 \\
\hline FRONT D'ORDRE & +.18 & -.02 & .16 & -.21 & -.10 & -.14 \\
\hline$\%$ ABSTENCIO & +.30 & +.16 & +.24 & -.47 & -.50 & +.69 \\
\hline
\end{tabular}

La incidència del comportament electoral històric en les eleccions de l'any 1977 es fa palesa si tenim en compte que en l'anàlisi de regressió múltiple en introduir la variable $" \%$ de vots del Front d'Esquerres de 1936» es millora considerablement l'ajust entre el vot esperat i el teal. ment obtingut per les diverses candidatures fins al punt que en algunes zones la "tradició de vot» sembla tenir un poder determinatiu més fort del comportament electoral que no pas les variables de classe social i dedicació professional, $\mathrm{i}$ així trobern que la tradició de vot és el millor indicador per determinar el vot del PSUC (+) i de la UCD (-) a Tarragona i del PDC $(+)$ i de la UCD (-) a Lleida, i té també un pes important en la determinació del vot PSC $(+)$ i PSUC $(+)$ a Barcelona. Aquí podem fer esment del que ja hem dit sobre el diferent lloc que un mateix partit ocupa en el ventall de forces polítiques de cada circumscripció. Com veiem, a Lleida, el PDC és situat en les zones més progressives de 1936, on el Front d'Esquerres hi feia bons resultats. Possiblement la candidatura de «Convergència i Unio» - - en les legislatives de 1979—, sense la imatge que li conferia el Partit Socialista-ex-Reagrupament, haurà presentat una imatge més conservadora que el PDC del 1977. 
Una primera aproximació a les eleccions legislatives de l'1 de març de 1979: estabilitat o canvi?

Aprovada la Constitució en el Referèndum de desembre de 1978, el gabinet Suárez decideix convocar eleccions legislatives abans de les eleccions municipals.

A Catalunya el quadre de partits i coalicions ba sofert lleugeres modificacions. La coalició «Socialistes de Catalunya» ha esdevingut un sol partit per la fusió dels dos collectius originaris (PSC i PSOE). Desfet el Pacte Democràtic per Catalunya, Convergència Democràtica de Catalunya pacta amb Unió Democràtica de Catalunya la candidatura "Convergència i Unión, i Alianza Popular, desptés de les aliances de Fraga amb Areilza i Osorio, es converteix en Coalició Democràtica mentre que el partit del govern - UCD - se sotmet a un procés de catalanització amb la incorporació d'Anton Cañellas i part del seu partit -uDC-u i del Centre $\mathrm{Ca}$ talà formant entre tots $\mathrm{Ia}$ coalició "Centristes de Catalunya» (CC-UCD). De tota manera el ventall de les grans opcions no s'ha modificat substancialment.

TAULA 5

Diferències 1977-1979 (eleccions legislatives)

Barcelona Girona Lleida Tarragona Catalunya

Diferència de percentatge

sobre cens electoral:

\begin{tabular}{|c|c|c|c|c|c|}
\hline Abstenció & $+12,5$ & $+9,7$ & $+13,4$ & $+8,7$ & $+12,0$ \\
\hline PSC/PSOE & $-4,2$ & 0,0 & $+4,4$ & $+1,2$ & $-2,9$ \\
\hline PSUC & $-3,2$ & $-1,5$ & $-2,6$ & $-3,0$ & $-2,9$ \\
\hline $\mathrm{PDC} / \mathrm{C}$ iU $\ldots . . . .$. & $-1,9$ & $-4,3$ & $-8,8$ & $-1,8$ & $-2,5$ \\
\hline $\mathrm{EC} / \mathrm{ERC}$ & $-1,1$ & $-0,9$ & $-0,9$ & $-0,4$ & $-0,9$ \\
\hline UCDCC & - & - & - & - & - \\
\hline UCD/CC-UCD ............ & $-0,8$ & $+2,8$ & $+1,5$ & $-2,0$ & $-0,5$ \\
\hline $\mathrm{AP} / \mathrm{CD}, \ldots \ldots \ldots \ldots \ldots$ & $-0,1$ & $-0,3$ & $-2,2$ & $-1,9$ & 0,0 \\
\hline
\end{tabular}

Els resultats (vegeu Taula 15) consoliden -amb lleugetes modificacions - el sistema de partits del 15 de juny de 1977 i, per tant, Catalunya continua diferenciant-se amb quatre formacions polítiques importants 
enfront del bipartidisme hegemònic de la resta de l'Estat. La tònica general de les eleccions va ésser el manteniment de les posicions obtingudes el 15 de juny de $1977 \mathrm{amb}$ un augment important de l'abstenció (+ 12 per cent) -vegeu Taula 5.

Els socialistes mantenen la seva posició hegemònica, retrocedint lleugerament a la ciutat de Barcelona i expandint-se a les comarques tarragonines i sobretot a les lleidatanes. El PSUC es manté amb lleugeres pèrdues, així com $\mathrm{ERC}$ i $\mathrm{CD}-\mathrm{AP}$-, mentre que «Convergència i Unió» augmenta lleugerament a la ciutat de Barcelona, es manté a les circumscripcions de Barcelona i Tarragona i sofreix pèrdues importants a Girona i, sobretot, a Lleida, on sembla que no ha incorporat l'electorat d'UDC i ha perdut el del PSC-R. La UCD es manté a Barcelona, augmenta a Lleida. i Girona i descendeix a Tarragona. En general es manté la concentració de vot (vegeu Taula 6) favorable als quatre primets partits, malgrat que a la circumscripció de Barcelona es presentaven 30 candidatures per al Congrés.

\section{TAULA 6}

Concentració de vot. Eleccions legislatives del 1977 i 1979

(\% sobre vots vàlids)

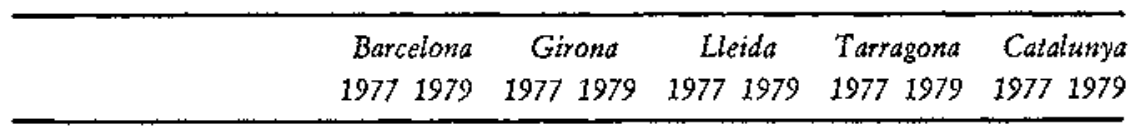

Percentatge obtingut pels partits que guanyen escons

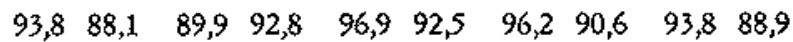

Percentatge obtingut pels

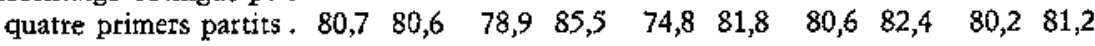

Quant a l'evolució de la tendència de vot podern veure la Taula 7, on és clar el manteniment de la tendència esquerrana de l'electorat des de $1936 .{ }^{\circ}$

9. Index de tendència vers l'esquerra:

$$
\begin{aligned}
& \text { 1936. Index. }=\frac{\% \text { vots Front d'Esquerses }}{\% \text { vots Front d'Ordre }} \times 100 \\
& \text { 1977. Index }=\frac{\%(\mathrm{PSC}+\mathrm{PSUC}+\mathrm{EC})}{\%(\mathrm{AP}+\mathrm{UCD}+\mathrm{UCDCC}+\mathrm{PDC})} \times 100
\end{aligned}
$$


Entre 1977 i 1979 l'esquerra sembla guanyar posicions a Tarragona i Lleida. Els índexs molt superiors de l'any 1936 són deguts al fet que una part de les forces de centre es va integrar en el Front d'Esquerres.

\section{TAula 7}

Evolució de l'índex de tendència a l'esquerra (1936-1979)

\begin{tabular}{lrrrc}
\hline & 1936 & 1977 & 1979 & Dif. 77/79 \\
\hline Barcelona ...... & 150 & 140 & 146 & +6 \\
Girona ......... & 125 & 68 & 78 & +10 \\
Lleida .......... & 120 & 54 & 85 & +31 \\
Tarragona ...... & 135 & 82 & 105 & +23 \\
Catalunya ...... & 141 & 120 & 140 & +20 \\
\hline
\end{tabular}

Nota: Index $=\frac{\% \text { vots d'esquerra }}{\% \text { vots de dreta }+ \text { vots de centre }} \times 100$.

En base als resultats d'una enquesta postelectoral, ${ }^{10}$ podem aproximarnos a l'estabilitat de l'opció dels electors del 1977 i a la trajectoria del seu vot del 1977 al 1979. Podem també intentar esbrinar quina ha estat l'actitud dels nous electors de 18-21 anys que podien votar per primera vegada.

Quant a l'estabilitat (vegeu quadre 8), el vot més estable sembla el del PSUC, seguit pel del PDC i PSC. El vot més inestable és el de AP-CD i EC-ERC.

Els electors més joves sembla que han privilegiat les opcions esquerranes $\mathrm{i}$ en segon loc les nacionalistes - $\mathrm{C}$ i U, BEAN. Només un $13 \%$ confessa haver-se abstingut lliurement, mentre que gairebé un $11 \%$ no

$$
\text { 1979. fndex. }=\frac{\%(\mathrm{PSC}+\mathrm{PSUC}+\mathrm{ERC})}{\%(\mathrm{CD}+\mathrm{CC}-\mathrm{UCD}+\mathrm{CiU})} \times 100
$$

10. Dades procedents d'una enquesta feta a Catalunya el mes de matç de 1979 per a La Vanguardia i realitzada per Sofemasa amb la collaboració de l'Equip de So. ciologia Electoral (UAB) -Mostra: 1.800 enquestes. 
«Papers»: Revista de Sociologia

\section{GRÀFIC 2}

Una aproximació a les trajectòries de vot -15 juny 1977 / 1 marc 1979a les quatre circumscripcions catalanes.
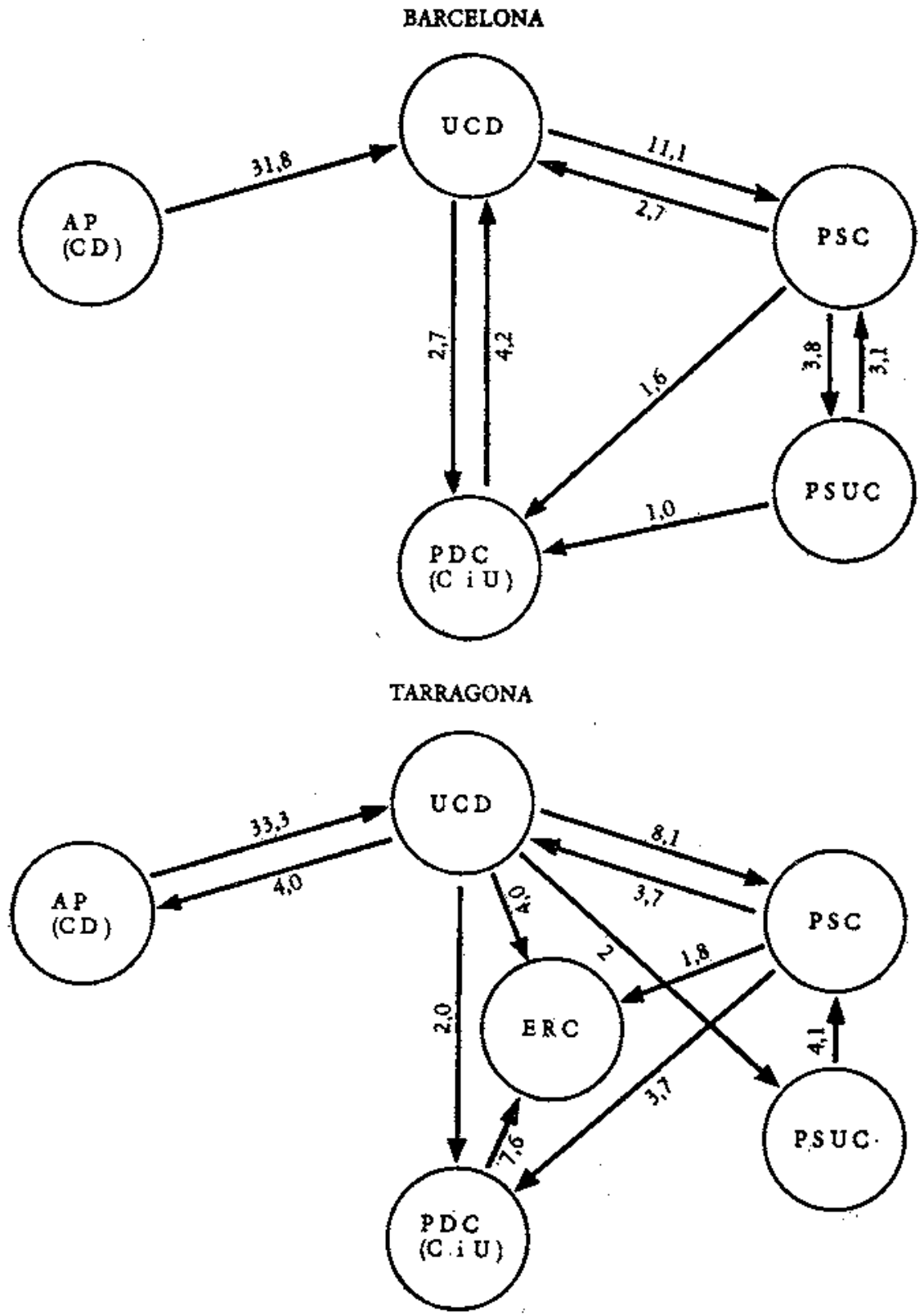
Comportament electorat a Catalunya el 15 de juny de 1977
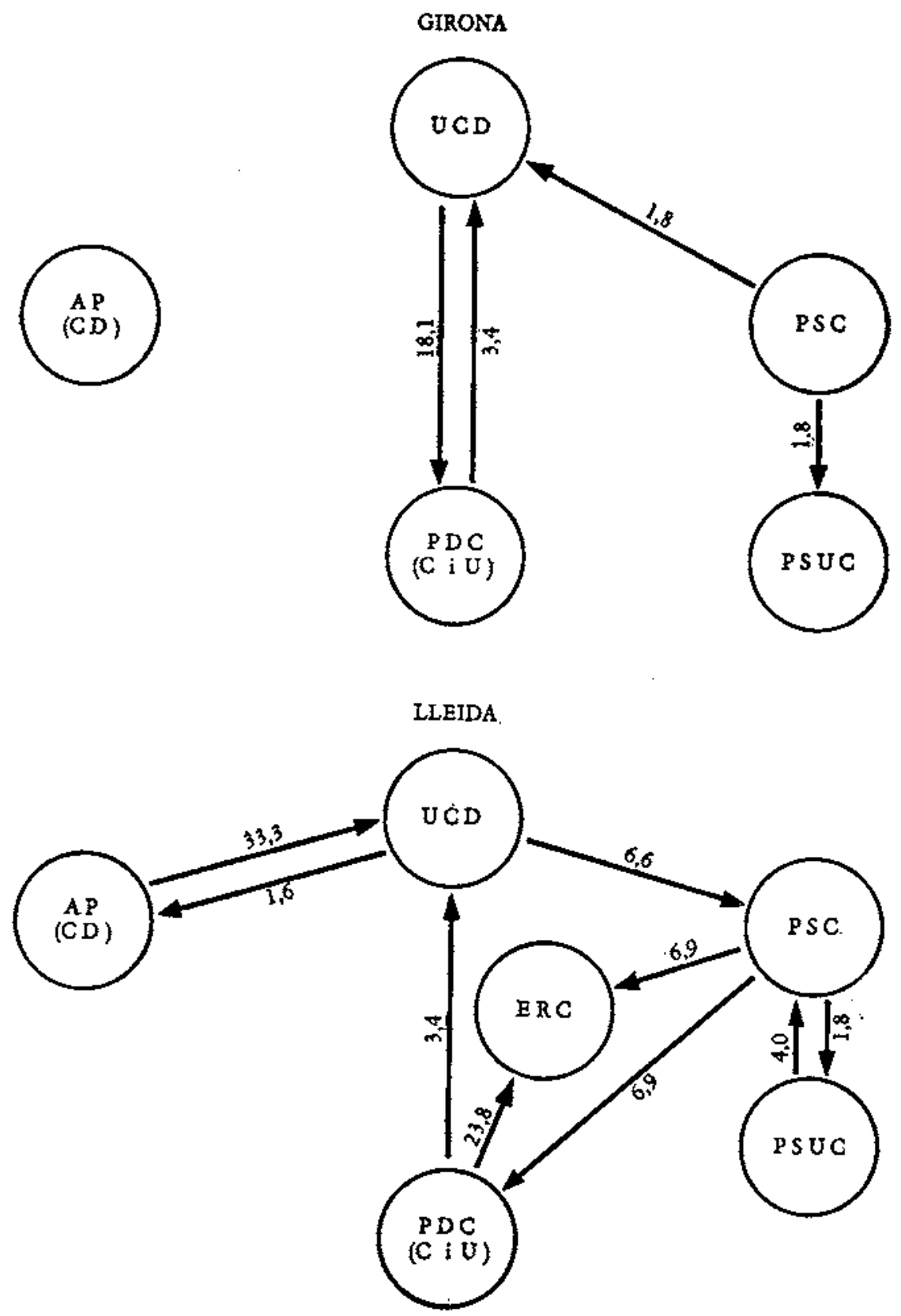
«Papers»: Revista de Sociologia

van poder votar per defectes de cens o per la impossibilitat de desplaçar-se al lloc on figuraven censats. Això apunta a una mobilitat de la població juvenil per motius d'estudis i de treball, mobilitat de cap manera reflectida en el cens de població. Un $10,8 \%$ no contesten la pregunta. (Vegeu Taula 9.)

\section{Taula 8}

Una aproximació a l'estabilitat de vot en les eleccions legislatives de $1977-1979$

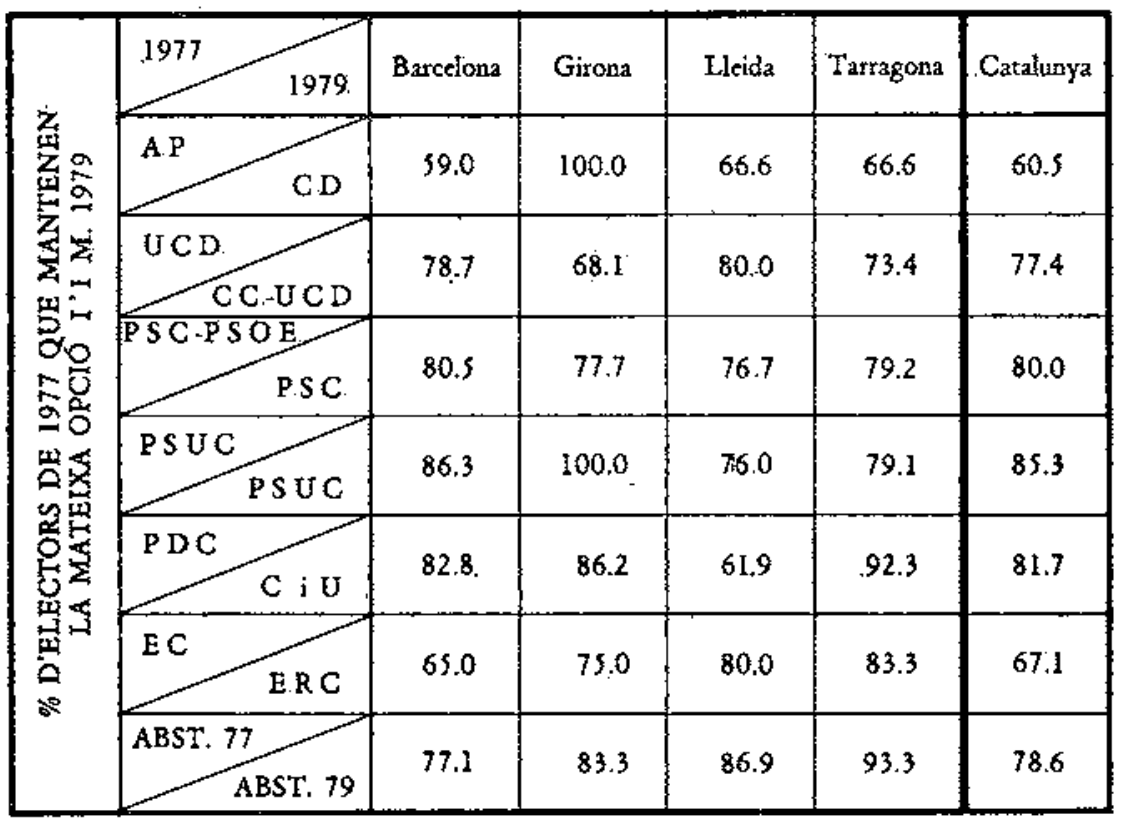

La trajectòria de vot dels electors de 1977 (vegeu Taula 10) ens permet veure un desplaçament substancial del vot AP-77 vers la candidatura CC-UCD, que es configura com l'única capaç d'aglutinar els interessos conservadors. També es detecta el transvasament d'un vot que el 1977 va donar suport al partit del govern i que el 1979 vota socialista. Les pèrdues de Convergència $\mathrm{i}$ Unió respecte al PDC són a favor d'UCD per la dreta i d'ERC per l'esquerra. EI transvasament PSC-PSUC i viceversa és equilibrat i l'abstenció sembla haver perjudicat totes les candidatures, sense diferències importants. 
En el Gràtic 2 podem veure una aproximació a les trajectòties de vot 1977-1979 en les quatre circumscripcions catalanes.

\section{TAULA 9}

Una aproximació a l'opció electoral dels joves de 18-21 anys en les eleccions legislatives de l'1 de març de 1979

\begin{tabular}{|c|c|c|c|c|c|c|c|c|c|c|c|c|c|c|}
\hline 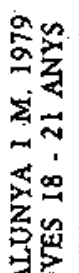 & 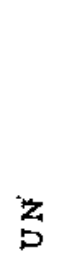 & $\stackrel{O}{O}$ & $\begin{array}{l}A \\
0 \\
0\end{array}$ & $\begin{array}{l}u \\
\text { un } \\
n_{1}\end{array}$ & $\begin{array}{l}0 \\
b \\
\text { 足 } \\
\text { n }\end{array}$ & $\begin{array}{l}p \\
0 \\
0\end{array}$ & $\begin{array}{l}0 \\
04 \\
04\end{array}$ & $\begin{array}{l}Z \\
\mathbb{Z} \\
m \\
m\end{array}$ & 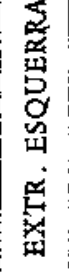 & 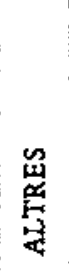 & 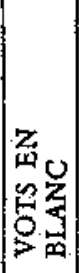 & 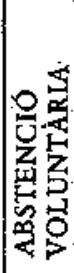 & 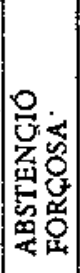 & 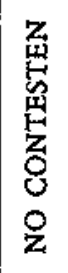 \\
\hline $\mathcal{G}$ & 2.3 & 0.0 & 6.9 & 21.7 & 13.9 & 5.4 & 6.2 & 3.8 & 1.4 & 2.1 & 1.5 & 13.1 & 10.9 & 10.8 \\
\hline
\end{tabular}

Les eleccions municipals del 3 d'abril de 1979 , malgrat el seu caràcter redicalment diferent quant a significació política, ens matisen algunes de les afimacions fetes en aquestes notes.

E1 vot nacionalista de centre confirma ei set arrelament en la ma* joria de comarques de Girona i Barcelona recuperant possiblement una part d'electorat que a les legislatives creien millor protegits els seus interessos votant el partit del govern. 
«Papers»: Revista de Sociologia

TAULA 10

Aproximació a la trajectòria del vot electoral de 1977 a 1979 a Catalınya

\begin{tabular}{|c|c|c|c|c|c|c|c|}
\hline 1979 & AP & \multicolumn{2}{c|}{ U C D } & PSC & PSUC & PDC & \multicolumn{2}{c|}{ EC } & ABST. \\
\hline CD & 60.5 & 0.6 & 0.0 & 0.0 & 0.0 & 0.0 & 0.0 \\
\hline CC-UCD & 31.5 & 77.4 & 2.6 & 0.0 & 4.0 & 2.8 & 2.8 \\
\hline PSC & 0.0 & 9.1 & 80.0 & 3.2 & 0.0 & 2.8 & 5.2 \\
\hline PSUC & 0.0 & 0.8 & 3.1 & 85.3 & 0.3 & 2.1 & 3.6 \\
\hline C i U & 0.0 & 3.7 & 2.0 & 0.8 & 81.7 & 2.8 & 0.9 \\
\hline ERC & 0.0 & 0.4 & 2.4 & 1.1 & 5.4 & 67.1 & 0.2 \\
\hline ABST. & 3.9 & 2.2 & 3.9 & 4.3 & 2.1 & 4.2 & 78.6 \\
\hline ALTRES I & 4.1 & 5.8 & 6.0 & 5.3 & 6.5 & 8.2 & 8.7 \\
\hline NO CONTESTA & 100 & 100 & 100 & 100 & 100 & 100 & 100 \\
\hline
\end{tabular}

Les eleccions municipals confirmen el fort gtau de determinació del vot comunista, precisament perquè, municipi per municipi, podern comprovar la forta implantació del vot al PSUC a la rodalia industrial de la ciritat de Barcelona.

Quant al vot Centristes de Catalunya-UCD, el seut retrocés a comarques, especiaiment a Tarragona, sembla confirmar la hipòtesi que les élites locals s'han estimat més presentar-se per «Convergència i Unió» que no pas per UCD. 
Comportament electoral a Catalunya el 15 de juny de 1977

\section{TAULA 11}

Resultats de les eleccions legislatives de 12 de febrer de 1936

\begin{tabular}{|c|c|c|c|c|c|c|}
\hline $12-11-1936$ & $\begin{array}{c}\text { Cens } \\
\text { electoral }\end{array}$ & Votants & $\begin{array}{c}\text { Absten- } \\
\text { cions }\end{array}$ & $\begin{array}{l}\text { Front } \\
\text { d'ordre }\end{array}$ & $\begin{array}{c}\text { Front } \\
\text { d'esquerres }\end{array}$ & $\begin{array}{c}\text { Inde- } \\
\text { pendents }\end{array}$ \\
\hline Barceiona ..... & 1.101 .612 & 741.042 & 360.570 & 295.757 & 445.285 & - \\
\hline \%6 s./cens ... & & 67,2 & 32,7 & 26,8 & 40,4 & - \\
\hline o s./votants. & & - & 一 & 39,9 & 60,1 & - \\
\hline Girona .......... & 201.209 & 142.113 & 59.096 & 63.086 & 79.027 & - \\
\hline$\%$ s. $/$ cens $\ldots$ & & 70,6 & 29,4 & 31,3 & 39,2 & - \\
\hline \% s./votants. & & - & $\rightarrow$ & 44,4 & 55,6 & - \\
\hline LLEIDA $\ldots . . \ldots \ldots$ & 183.593 & 130.321 & 53.272 & 57.741 & 69.520 & 3.060 \\
\hline$\%$ s. $/$ cens $\ldots$ & & 70,9 & 29,0 & 31,4 & 37,8 & 1,8 \\
\hline \% s./votants. & & - & 一 & 44,3 & 53,3 & 2,3 \\
\hline TARRAGONA .... & 220.549 & 163.488 & 57.059 & 68.579 & 93.111 & 1.800 \\
\hline$\%$ s. $/$ cens ... & & 74,1 & 25,8 & 31,1 & 42,2 & 0,8 \\
\hline$\% \mathrm{~s} /$ votants. & & - & - & 41,9 & 56,9 & 1,1 \\
\hline Cataluunya ..... & 1.706 .963 & 1.176 .959 & 529.997 & 485.163 & 686.943 & 4.860 \\
\hline$\%$ s./cens ... & & 68,9 & 31,0 & 28,4 & 40,2 & 2,8 \\
\hline$\%$ s./votants. & & - & - & 41,2 & 58,3 & 0,4 \\
\hline
\end{tabular}

Fonts: Elaborats a partir dels resultats per municipi publicats at Bulletí de la Generalitat de Catalunya (febrer 1936) i pel cens electoral de l'any 1934.

Les municipals del 3 d'abril confirmen la capacitat d'expansió dels socialistes a les comarques rurals i a la ciutat de Barcelona, i retrocedeixen en part en la rodalia industrial, a favor dels comunistes, retrocés que pot ésser degut al fet que l'i de març un sector de l'electorat comunista va donat suport a l'estratègia d'alternativa de govern del PSOE. 
«Papers»: Revista de Sociologia

\section{TAULA 12}

Resultats electorals a les comarques de Catalunya en les eleccions del 12 de febrer de 1936

\begin{tabular}{|c|c|c|c|c|c|c|}
\hline & Comarques & Electors & \% F. Ordre & \%o Front Esq. & $\%$ Indep. & $\%$ Abst. \\
\hline 1. & Baix Liobregat ... & 50.169 & 28,7 & 45,2 & 0,0 & 26,0 \\
\hline 2. & Barcelonès .......... & 671.964 & 28,9 & 39,3 & 0,0 & 37,5 \\
\hline 3. & Maresme ............ & 60.634 & 36,6 & 39,5 & 0,0 & 23,8 \\
\hline 4. & Vallès Occidental . & 87.439 & 28,9 & 48,2 & 0,0 & 22,8 \\
\hline 5. & Vallès Oriental .... & 36.719 & 36,3 & 34,0 & 0,0 & 29,6 \\
\hline 6. & Alt Penedès ......... & 29.225 & 30,5 & 47,6 & 0,0 & 21,8 \\
\hline 7. & Garraf ................ & 18.250 & 28,8 & 48,1 & 0,0 & 23,0 \\
\hline 8. & Anoia & 27.412 & 33,7 & 37,8 & 0,0 & 28,5 \\
\hline 9. & Bages $\ldots \ldots \ldots \ldots \ldots$ & 56.206 & 32,5 & 41,9 & 0,0 & 25,5 \\
\hline 10. & Betguedà ............. & 24.289 & 34,5 & 37,9 & 0,0 & 27,6 \\
\hline 11. & Osona $\ldots \ldots \ldots \ldots+\ldots \ldots$ & 41.379 & 38,6 & 34,2 & 0,0 & 27,1 \\
\hline 12. & La Selva ................ & 29.654 & 37,0 & 36,6 & 0,0 & 26,3 \\
\hline 13. & Gironès ............... & 44.057 & 34,5 & 38,4 & 0,0 & 27,0 \\
\hline 14. & Baix Empordà ..... & 33.287 & 31,1 & 42,2 & 0,0 & 26,7 \\
\hline 15. & Alt Empordà ....... & 42.988 & 26,0 & 39,9 & 0,0 & 34,0 \\
\hline 16. & Gatrotxa $\ldots \ldots \ldots \ldots$ & 24.428 & 33,9 & 35,5 & 0,0 & 30,6 \\
\hline 17. & Ripollès $\ldots . . . \ldots \ldots . .$. & 20.359 & 25,5 & 45,1 & 0,0 & 29,4 \\
\hline 18. & Cerdanya ............. & 7.256 & 23,6 & 40,4 & 0,1 & 35,9 \\
\hline 19. & Alt Urgell ........... & 12.037 & 32,0 & 28,9 & 1,0 & 38,5 \\
\hline 20. & Pallars Sobirà ...... & 6.989 & 25,3 & 30,4 & 8,4 & 37,3 \\
\hline 21. & Vall d'Aran .......... & 3.700 & 22,1 & 39,5 & 16,8 & 30,9 \\
\hline 22. & Pallars Jussà ....... & 14.811 & 20,2 & 34,9 & 9,5 & 40,4 \\
\hline 23. & Solsonès .............. & 6.252 & 45,2 & 15,6 & 1,3 & 38,7 \\
\hline 24. & La Noguera ......... & 29.357 & 32,1 & 37,7 & 2,5 & 28,6 \\
\hline 25. & Urgell ............... & 23.629 & 39,8 & 34,6 & 0,7 & 24,0 \\
\hline 26. & Segarra ................ & 13.339 & 36,4 & 27,3 & 1,3 & 33,6 \\
\hline 27. & Segrià ............... & 51.372 & 27,8 & 47,3 & 1,0 & 23,9 \\
\hline 28. & Les Garrigues ..... & 19.526 & 35,3 & 40,5 & 0,2 & 24,2 \\
\hline 29. & Conca de Batbetà & 16.988 & 31,9 & 38,9 & 0,4 & 28,7 \\
\hline 30. & Alt Camp .............. & 20.372 & 30,8 & 45,8 & 0,2 & 23,2 \\
\hline 31. & Baix Penedès ....... & 10.371 & 24,9 & 47,9 & 0,2 & 26,9 \\
\hline 32. & Tarragonès ........... & 30.272 & 31,6 & 45,0 & 0,4 & 22,9 \\
\hline 33. & Baix Camp …...... & 37.990 & 30,6 & 44,2 & 0,1 & 24,9 \\
\hline 34. & Priorat $\ldots \ldots \ldots \ldots \ldots \ldots$ & 12.577 & 34,4 & 36,8 & 0,1 & 28,6 \\
\hline 35. & Ribera ................ & 17.650 & 30,8 & 37,9 & 0,0 & 31,2 \\
\hline 36. & Terra Aita .......... & 13.303 & 43,1 & 31,1 & 0,2 & 25,5 \\
\hline 37. & Baix Ebte ........... & 35.018 & 26,9 & 44,2 & 1,1 & 27,8 \\
\hline 38. & Montsià ............. & 25.688 & 31,1 & 41,7 & 4,1 & 22,9 \\
\hline
\end{tabular}

Notes: \% sobre cens electoral.

Font: Elaboracio a partir dels resultats per municipi publicats al Butllets de lo Generalitat de Catainya (febrer 1936). 


\section{TAULA 13}

Resultats electorals del 15 de juny de 1977 a Catalunya

\begin{tabular}{|c|c|c|c|c|c|c|c|c|c|c|c|}
\hline 15-VI-1977 & $\begin{array}{c}\text { Cens } \\
\text { electoral }\end{array}$ & Votonts & $\begin{array}{l}\text { Absten- } \\
\text { cions }\end{array}$ & $\begin{array}{l}\text { PSC/ } \\
\text { PSOE }\end{array}$ & PSUC & $P D C$ & $U C D$ & $U C D C C$ & $E C$ & $A P$ & Altres \\
\hline BARCELONA $\ldots \ldots \ldots \ldots \ldots$ & 3.035 .289 & 2.406 .770 & 628.519 & 732.219 & 475.919 & 372.546 & 362.260 & 129.072 & 110.084 & 75.514 & 149.156 \\
\hline$\%$ s./electors $\ldots . \ldots . .$. & & 79,3 & 20,7 & 24,1 & 15,7 & 12,3 & 11,9 & 4,2 & 3,6 & 2,5 & 4,9 \\
\hline \% s./votants $\ldots . \ldots \ldots$ & & - & - & 30,4 & 19,8 & 15,5 & 15,0 & 5,4 & 4,6 & 3,1 & 6,2 \\
\hline Girona ................. & 307.396 & 250.255 & 57.141 & 60.666 & 24.387 & 67.204 & 45.225 & 13.348 & 6.169 & 7.954 & 24.810 \\
\hline$\%$ s./electors ......... & & 81,4 & 18,6 & 19,7 & 8,1 & 21,8 & 14,7 & 4,3 & 2,0 & 2,6 & 8,1 \\
\hline$\%$ s./votants .......... & & - & 一 & 24,2 & 9,9 & 26,8 & 18,0 & 5,3 & 2,5 & 3,2 & 9,9 \\
\hline LLEIDA & 239.553 & 188.688 & 50.865 & 27.801 & 22.696 & 45.412 & 45.222 & 17.583 & 14.118 & 10.066 & 5.790 \\
\hline$\%$ s./electors ......... & & 78,8 & 21,2 & 11,6 & 9,5 & 19,0 & 18,9 & 7,3 & 5,9 & 4,2 & 2,4 \\
\hline \% s./votants .......... & & - & - & 14,7 & 12,0 & 24,1 & 24,0 & 9,3 & 7,5 & 5,3 & 3,0 \\
\hline TARRAGONA $\ldots \ldots \ldots \ldots \ldots$ & 329.793 & 255.599 & 74.194 & 59.473 & 41.072 & 36.898 & 68.550 & 14.074 & 10.788 & 15.143 & 9.601 \\
\hline$\%$ s./electors . ........ & & 77,5 & 22,5 & 18,0 & 12,4 & 11,2 & 20,8 & 4,3 & 3,4 & 4,6 & 3,0 \\
\hline$\%$ s./votants .......... & & - & - & 23,3 & 16,1 & 14,4 & 26,8 & 5,5 & 4,2 & 5,9 & 3,7 \\
\hline Catalunya $\ldots \ldots \ldots \ldots \ldots$ & 3.912 .031 & 3.101 .312 & 880.159 & 880.159 & 564.574 & 522.060 & 521.357 & 174.077 & 141.159 & 108.677 & 141.912 \\
\hline \% s./electors ......... & & 79,3 & 20,7 & 22,5 & 14,4 & 13,3 & 13,3 & 4,4 & 3,6 & 2,7 & 3,6 \\
\hline \% s./votants ......... & & - & - & 28,4 & 18,2 & 16,8 & 16,8 & 5,6 & 4,5 & 3,5 & 4,6 \\
\hline
\end{tabular}

Font: Vegeu resultats complets a Equip de Sociologia Electoral, Resum dels resultats de les eleccions legislatives del 15 de juny de 1977 (Barcelona: CIDC, 1978). 
«Papets»: Revista de Sociologia

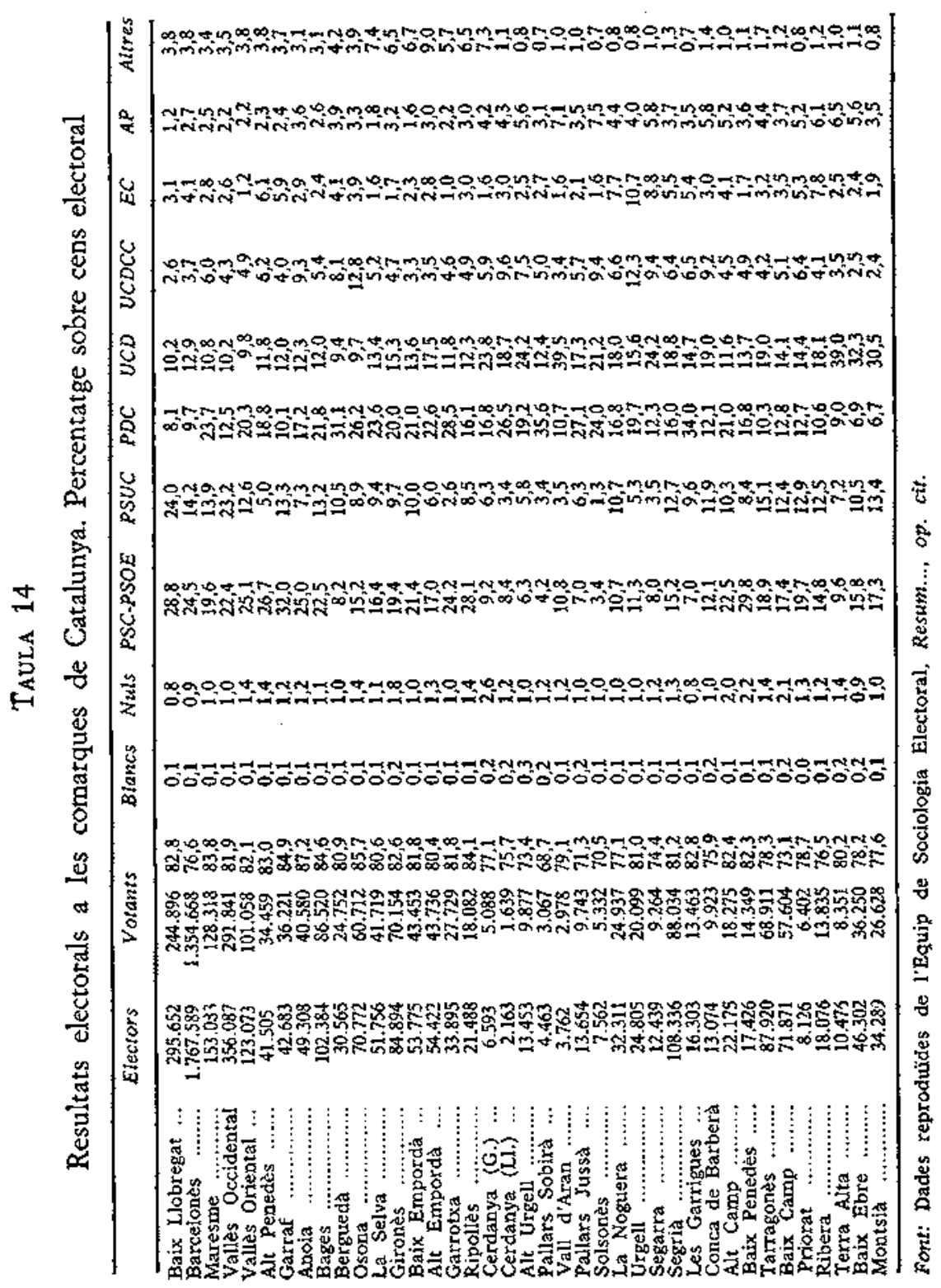




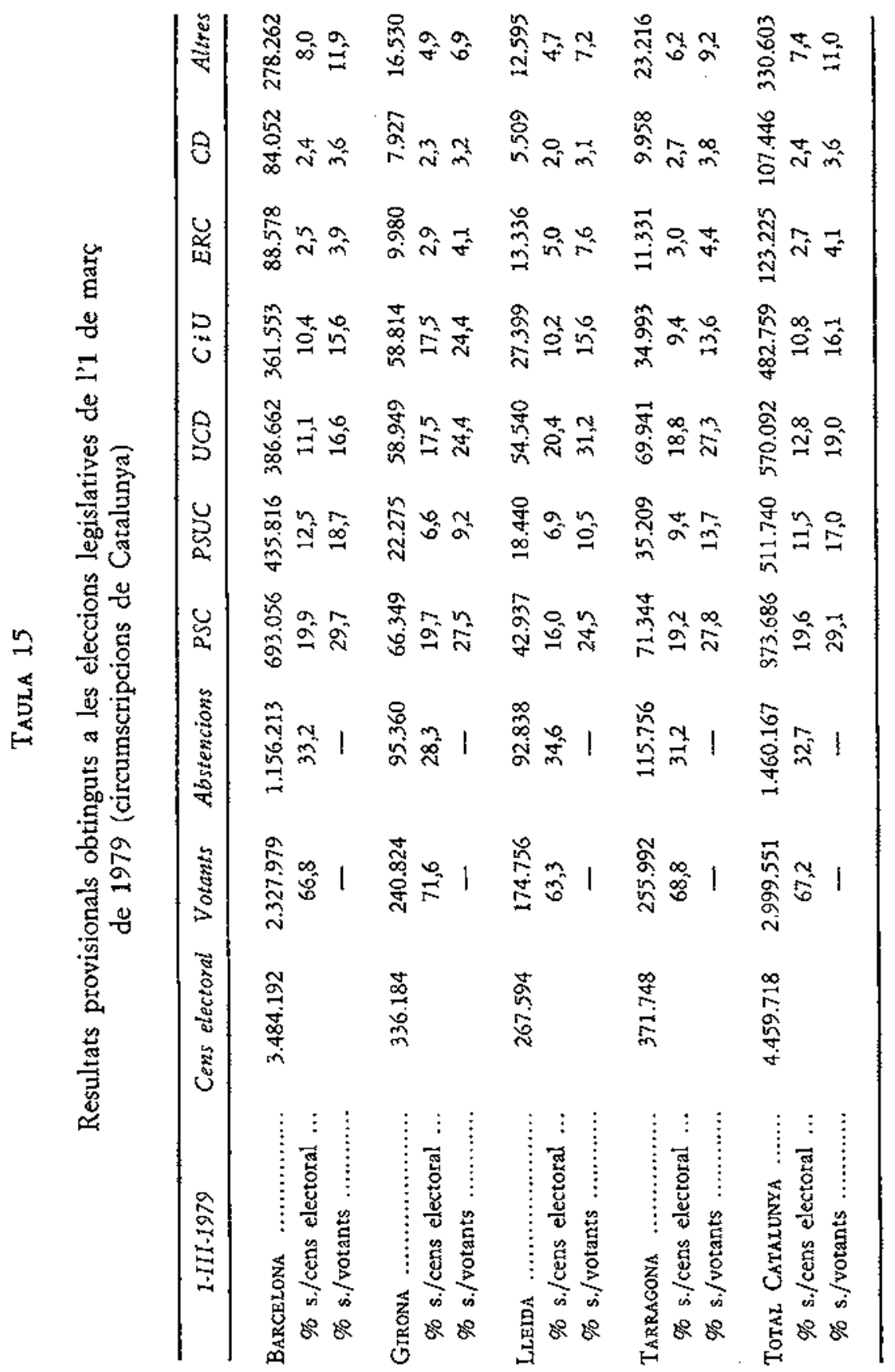


«Paperss: Revista de Sociologia

En darrer terme, les eleccions locals confirmen l'increment de l'abstenció a partir del Referèndum de 1978. Aquesta preocupant desafecció de part del cos electoral envers les consultes electorals exigeix una anàlisi aprofundida per tal de determinar-ne les causes.

ROSA VIRós

Facultat de Ciències Econòmiques

Universitat de Barcelona (Pedralbes)

Barcelona 